\title{
Open access, moving to the fore
}

\author{
Kuan-Teh Jeang
}

\section{Abstract}

Nine years after its founding, Retrovirology has moved to the forefront of virology journals in Impact Factor.

In 2004, during the early days of Open Access, I had the opportunity to start Retrovirology employing the then "new way" of publishing [1]. Retrovirology was not the first journal that I helped found. Ten years earlier, in 1994, I was one of nine editors, led by Dr. Chuan C. Chang, who started the Journal of Biomedical Science [2]. The Journal of Biomedical Science originated as a subscription-based journal; thus, when Retrovirology began I understood the difference between a publishing model based on subscription (readers/subscribing libraries and institutions pay) versus Open Access (authors pay, and all articles are freely accessible by readers).

At the outset, there were two challenges to Retrovirology's success. The first was whether Open Access would be a sustainable business model. In those days, this was an unknown. Today, the increasing popularity of journals like PLoS ONE, Nature's Scientific Reports (www.nature.com/srep/index.html), Cell Reports (www.cellreports. cell.com), Cell and Bioscience [3], Journal of the International AIDS Society (www.jiasociety.org/index.php/ jias), and the recent migration of journals such as $E M B O$ Molecular Medicine from a subscription to an Open Access format indicate that the latter business model has achieved financial traction, if not overt profitability.

The second challenge was an early notion held by some that Open Access journals would publish lower "quality" science with inherently less "visible" findings. A few contentious colleagues even insisted, "Retrovirology will never reach the Impact Factors of the Journal of Virology, Virology, and the Journal of General Virology!" In retrospect, they were wrong; Retrovirology achieved and surpassed those metrics. Indeed, in the 2011 tabulation of Impact Factor and Immediacy Index, Retrovirology placed ahead of the Journal of Infectious Diseases, AIDS,

Correspondence: kjeang@nih.gov

The National Institutes of Health, Bethesda, MD, USA
JAIDS, J Virol., Virology, J Gen Virology; and two established standards of molecular biology and biochemistry, the Journal of Molecular Biology and the Journal of Biological Chemistry (Figure 1). Of interest, amongst these journals, Retrovirology is the only Open Access journal. This means that only in Retrovirology are your papers immediately available for all to read, the very day that they are published, in full text form without the readers being encumbered by subscription fees. This Open Access feature may explain the large advantage in Immediacy Index for papers published in Retrovirology over the next-ranked journal, the Journal of Infectious Diseases (Figure 1).

Impact Factor and Immediacy Index are two of several proxies of a journal's quality, and one should interpret cautiously their meaning [4]. Arguably, a better measure is to ask how a journal's papers have made a difference in its field. In this respect, a significant example can be drawn from six Retrovirology papers published in December 2010 that were the first to pivotally correct the then held belief that XMRV was an etiological cause of Chronic Fatigue Syndrome (CFS) [5-10]. In that instance, Retrovirology's Open Access format was particularly instrumental in permitting interested individuals, who were not career scientists, to freely, rapidly, and fully access those paradigm-changing peer-reviewed publications.

Increasing data support the absence of inherent reasons for qualitative difference between papers published in subscription versus Open Access journals [11]. In my view, whether a journal moves to the fore is dictated by the diligence and dedication of its editorial board. Retrovirology's strong progress forward is owed to the efforts of its board members (http://www.retrovirology.com/ about/edboard).

\section{Acknowledgements}

I thank Andrew Dayton, Mark Wainberg, and John Semmes for critical readings of this editorial. The opinions expressed here are my personal views 


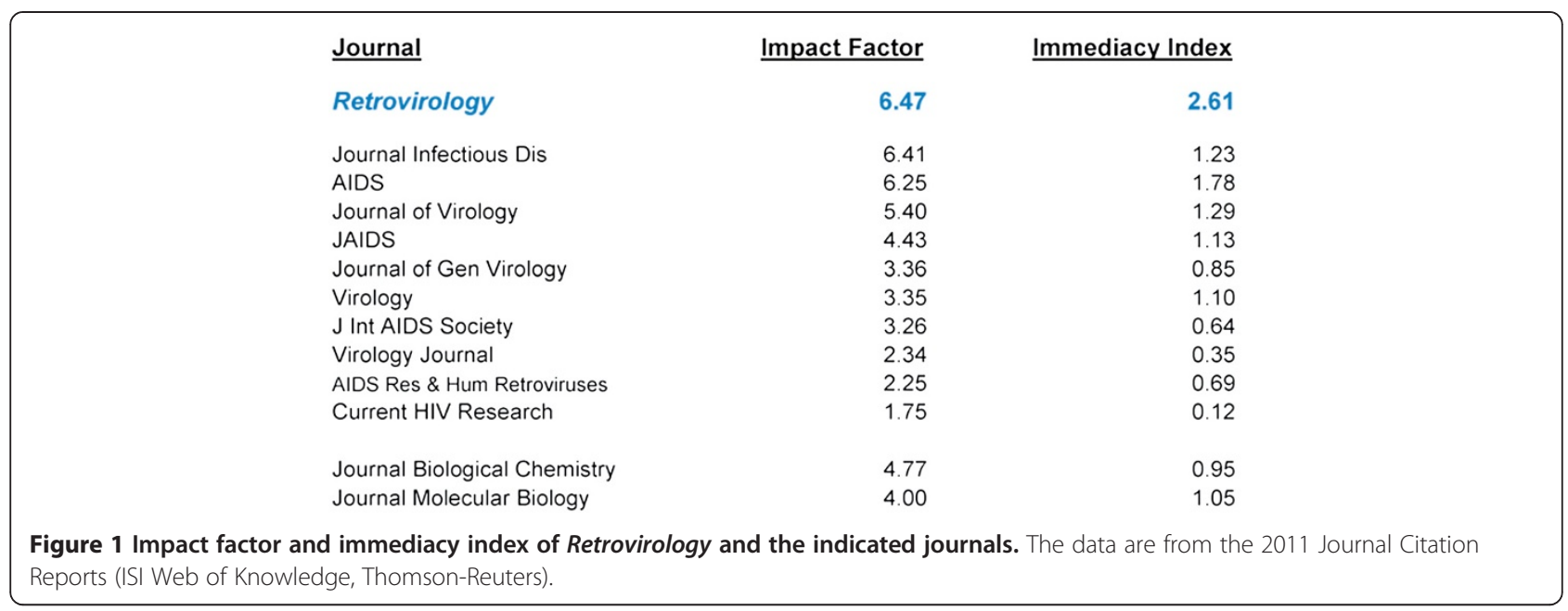

and do not necessary reflect the views of my employer, the National Institutes of Health, USA. Work in my laboratory is funded in part by intramural support from the National Institute of Allergy and Infectious Diseases, NIAID.

Received: 31 July 2012 Accepted: 3 August 2012

Published: 13 August 2012

\section{References}

1. Jeang KT: Retrovirology and young Turks. Retrovirology 2004, 1:1.

2. Jeang KT: If You Build It, They Will Come. J Biomed Sci 1996, 3(2):67-68.

3. Jeang KT: If you organize, they will join. Cell Biosci 2011, 1(1):2.

4. Jeang KT: Impact factor, $\mathrm{H}$ index, peer comparisons, and Retrovirology: is it time to individualize citation metrics? Retrovirology 2007, 4:42.

5. Robinson MJ, Erlwein OW, Kaye S, et al: Mouse DNA contamination in human tissue tested for XMRV. Retrovirology 2010, 7:108.

6. Oakes B, Tai AK, Cingoz O, et al: Contamination of human DNA samples with mouse DNA can lead to false detection of XMRV-like sequences. Retrovirology 2010, 7:109.

7. Sato E, Furuta RA, Miyazawa T: An endogenous murine leukemia viral genome contaminant in a commercial RT-PCR kit is amplified using standard primers for XMRV. Retrovirology 2010, 7:110.

8. Hue S, Gray ER, Gall A, et al: Disease-associated XMRV sequences are consistent with laboratory contamination. Retrovirology 2010, 7(1):111.

9. Smith RA: Contamination of clinical specimens with MLV-encoding nucleic acids: implications for XMRV and other candidate human retroviruses. Retrovirology 2010, 7:112.

10. Stoye JP, Silverman RH, Boucher CA, Le Grice SF: The xenotropic murine leukemia virus-related retrovirus debate continues at first international workshop. Retrovirology 2010, 7:113.

11. Bjork BC, Solomon D: Open access versus subscription journals: a comparison of scientific impact. BMC Med 2012, 10:73.

\section{Submit your next manuscript to BioMed Central and take full advantage of:}

- Convenient online submission

- Thorough peer review

- No space constraints or color figure charges

- Immediate publication on acceptance

- Inclusion in PubMed, CAS, Scopus and Google Scholar

- Research which is freely available for redistribution 